\title{
Academic Achievement Motivation among Junior College Science Faculty Students
}

\author{
Dr. Sujit Dhanraj Kumavat ${ }^{1 *}$
}

\section{ABSTRACT}

For students there is great need of motivation, because motivation effects on their academic achievement. The present study is about the academic achievement motivation of the junior college 12th class Science faculty students. Achievement motivation plays an important role to achieve educational goals of the students. The objective of the present study was to find out the achievement motivation among junior college science faculty student. The hypothesis of the research was there was significant difference between boys and girl student in the dimension achievement motivation. The sample for the present research selected from the junior college in Ahmednagar district. For the research, 12th class 96 students of science faculty were selected. The age range of the students were 17 to 18 years $(M=27.79 \mathrm{SD}=3.56)$. Random sample method was used to sample collection. The data was analyzed with t-test. Result was showed that Girls students had more academic achievement motivation than boy's students of science faculty.

\section{Keywords: Achievement Motivation, Junior college student}

Educated manpower is the emerging need of any nation as educated and skilled human resource is asset for any country. It becomes indispensable to develop human resource from the early stages of human life; Children are to be set to develop realistic aspiration encompassing their lives, education and prospects of the future. Therefore, correlates to academic achievement draw the attention of researches. Among the correlates at present psycho-social variables are gaining importance. Self-concept and Achievement motivation is such a psycho-social variable which is also responsible in a great way effecting academic achievement in children. One of the most persistent puzzles confronting parents and teachers is uneven academic achievement among equally able students. What factors cause some students to go above and beyond their personal and environmental constraints is the focal interest of current social- cognitive theories of motivation and action. One of the parts of achievement is academic motivation.

\footnotetext{
${ }^{1}$ Faculty, Pemraj Sarda College, Ahmednagar, India) (Faculty, Pemraj Sarda College, Ahmednagar, India *Responding Author

Received: March 9, 2017; Revision Received: March 28, 2017; Accepted: March 30, 2017

(C) 2017 Kumavat S; licensee IJIP. This is an Open Access Research distributed under the terms of the Creative Commons Attribution License (www.creativecommons.org/licenses/by/2.0), which permits unrestricted use, distribution, and reproduction in any Medium, provided the original work is properly cited.
} 


\section{Academic Achievement Motivation among Junior College Science Faculty Students}

Academic motivation is defined as enthusiasm for academic achievement which involves the degree to which students possess certain specific behavioral characteristics related to motivation (Hwang et al, 2002). It is the orientation to the actions which is important to compel with the perfect standards. Goc (2010) has stated the factors affecting students' achievement motivation as effectiveness of the teacher, friends, the individual's attitude towards school, students' perceptions about their own abilities, past experiences positive or negative, the importance given to the student's success, parent's approaches towards their children and school / college.

In this rapidly changing world and with the growing advancement in science and information technology, the place of education has become so vital that every parents today sets high goals to educate his/her child. It is a common observation that success in the academic achievement saves as an emotional tonic and any damage done to a child may be partially repaired by the success in college. Sound development in academic can will be matched with pillars on which entire future structure of personality stands and a good academic record of students is an index of an effective educational system. In more general term, academic achievement means the achievement of the pupils in so-called academic subjects. Therefore, academic achievement may be defined as a measure of knowledge, understanding or skills in a specific subjects or a group for subjects. Academic achievement is not a unique dimensional; multidimensional phenomenon. So, differences in academic achievement can be attributed to one single factor but to a large number of factors those affect academic achievement. The factors on which achievement depends are innumerable e.g. intelligence, motivation, creativity, achievement motivation, personality, socioeconomic status etc. However, it was not possible to take them up all these factors one time due to constraints of time and resources, achievement motivation.

In the past decades because of the effect of motivation for academic achievement on students' success, psychologists have recognized and examined the effective factors in motivation for academic achievement. The results of their research indicated that personality, family, university and social variables are related to this construct (Masaali, 2007). Others directed their studies towards integrating intellectual ability, learning style, personality and motivation for academic achievement as the predictors of academic achievement in higher education (Busato, Prinsb, Elshouta \& Hamakera, 2009). In another study, the motivation in students of dentistry was reported differently across males and females. (Gallagher, Patel, Donaldson, Wilson, 2007). In a research on students of dentistry, for example, male students were more concerned about the factor of income and female students cared more about family's recommendations (Hashemipour, 2006).

In a research comprising several field studies and laboratory experiments, (Boggiano et al 1992) revealed that achievement motivation positively influenced academic performance. Children with an intrinsic motivation orientation had higher reading and math's scores and higher overall achievement scores compared to their extrinsic counterparts (Boggiano et-al 1992). There is a 


\section{Academic Achievement Motivation among Junior College Science Faculty Students}

significant correlation between academic achievement and motivation (Sikwari 2014) and motivation has impact on academic achievement of secondary school students in mathematics with respect to gender (Tella 2007). Highly motivated students performed better academically than lowly motivated students (Tella 2007) and females are highly motivated compared to their male counterparts.(Sikwari 2014).

\section{Objectives of the Study}

To compare academic achievement motivation of junior college, science faculty students.

\section{Hypotheses of the study}

There is significant difference in academic achievement motivation among boys and girls of junior college science faculty students.

\section{METHODOLOGY}

For the present research the sample was selected from a junior college of science faculty Ahmednagar (Maharashtra). Total 96 students were selected of $12^{\text {th }}$ class science faculty. Among them 48 student were boys and another 48 students were girls. The age range of the students were 17 to 18 years $(M=27.79 S D=3.56)$. Simple random probability technique was used for sampling.

\section{Tools}

The tool used for the present study was Academic Achievement Motivation Test (AAMT) constructed by Dr. T.R. Sharma (1984). It has 35 items and the maximum possible score is 35. Each item of the test is scored as either +1 or 0 .

\section{Statistical Techniques}

Mean, S.D. and t-test were used for the data analysis.

\section{RESULT AND DISCUSSION}

The following result shown that comparison between boy and girls science faculty junior college student for Academic Achievement Motivation Test.

Table 1 Mean, S.D, df, std error mean, $t$ value of boys and girls of junior college science faculty students.

\begin{tabular}{|l|l|l|l|l|l|l|l|}
\hline Students & Mean & Std. Deviation & N & df & Std. Error Mean & t value & Sign. \\
\hline Boy & 27.0625 & 3.91074 & 48 & 94 & .36422 & 76.304 & 0.01 \\
\hline Girl & 28.5208 & 3.05962 & 48 & & & \\
\hline
\end{tabular}




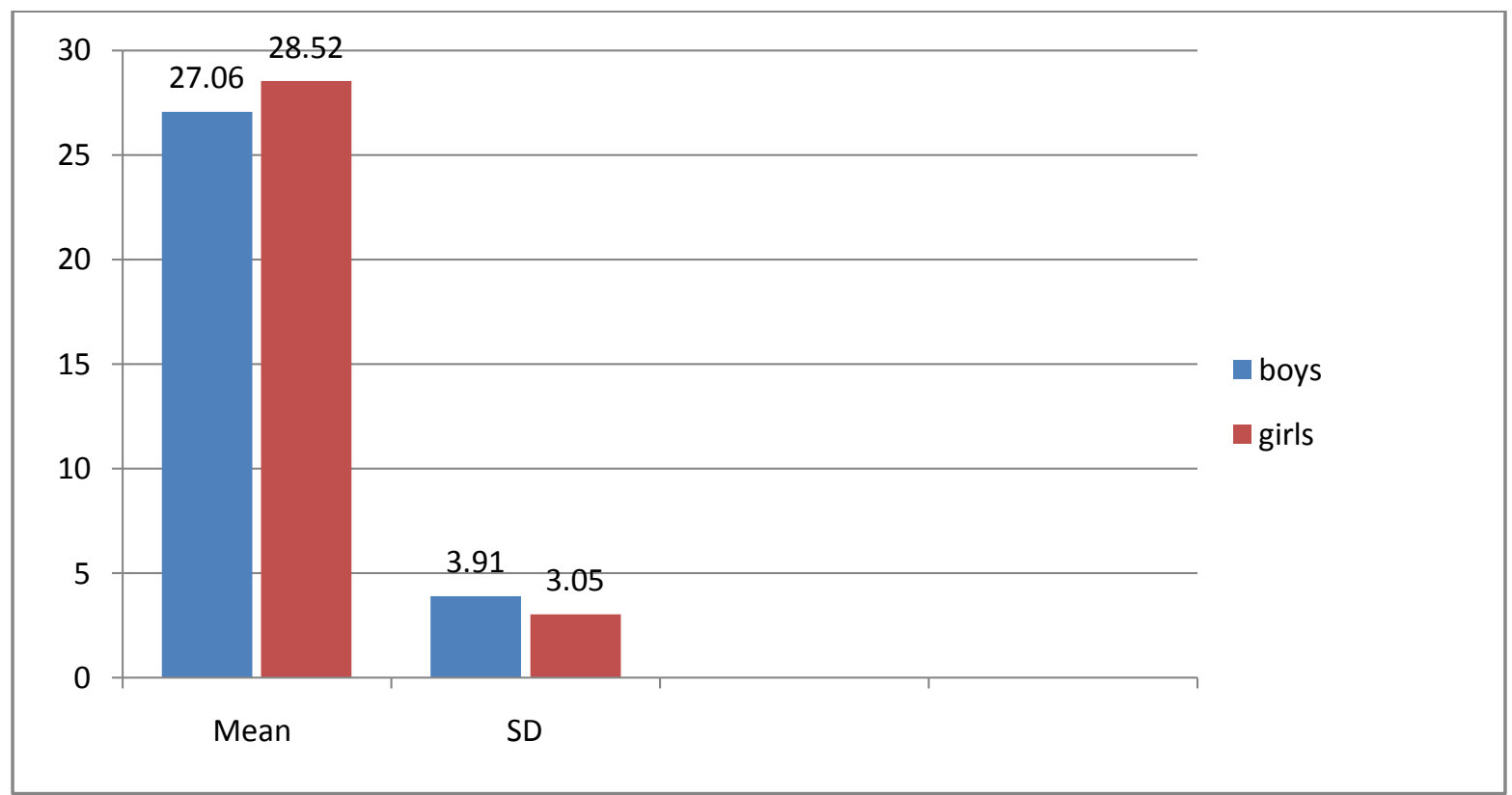

Figure 1 Comparison of Mean and SD of Junior college science faculty students for Academic Achievement Motivation Test.

The table 1and figure 1 showed the comparison of boys and girls of $12^{\text {th }}$ class science faculty student with respect to academic achievement motivation. The mean value of boys was 27.06 and SD was3.91.The mean value of girls was 28.52 and SD was 3.05. The t-value was 76.304 which is significant at 0.01 level. Thus the hypothesis "There is significant difference in academic achievement motivation among boys and girls of junior college science faculty students." was accepted. It means that there is significant difference between boys and girls of junior college science faculty students for academic achievement motivation. The mean value of boys was 27.06 and SD was3.91.The mean value of girls was 28.52 and SD was 3.05. The mean value of girls was higher than the boys which mean that girls have more academic achievement motivation than the boys.

Similar result found from Joshi and Srivastava (2009). They were found significantly gender differences in academic achievement motivation. Girls were significantly higher on academic achievement as compared to boys.

\section{CONCLUSION}

There was significant difference in boys and girls of junior college science faculty students in academic achievement motivation. Girls have more academic achievement motivation than the boys. 


\section{Academic Achievement Motivation among Junior College Science Faculty Students}

\section{Acknowledgments}

The author appreciates all those who participated in the study and helped to facilitate the research process.

Conflict of Interests: The author declared no conflict of interests.

\section{REFERENCES}

Boggiano, A. K., Shields, A., Barrett, M., Kellam, T., Thompson, E., Simons, J., \& Katz, P. (1992). Helpless deficits in students: The role of motivational orientation. Motivation and Emotion, 16, 3, 271-296.

Busato VV, Prinsb FJ, Elshouta JJ, Hamakera $\mathrm{CH}$. Intellectual ability, learning style, personality, achievement motivation and academic success of psychology students in higher education. [cited2009May3]. Available from http://www.sciencedirect.com/ science?

Goc, T. (2010). M. A. Thesis, Dokuz Eylul University, Izmir, Turkey. Hassanzadeh R, Amuee N (Translators). [Angizesh baraye yadgiry (as nazariyye ta amal)]. Stapic DJ (Author). Tehran: Donyaye pajohesh. 2001.

Hwang, Y. S., Echols, C., \& Vrongistinos, K. (2002). Multidimensional academic motivation of high achieving African American students. College Student Journal,36(4), 544-554.

Joshi, S. and Srivastava, R. (2009). Self-esteem and Academic Achievement of Adolescents, Journal of the Indian Academy of Applied Psychology. Vol. 35, Special issue, Pp,33-39.

Masaali S. [Relationship between reading study and academic achievement among students in $I U]$. [disseration]. Isfahan: Khorasgan Slamic Azad University.2007.

Sikhwari T.D (2014): A study of the Relationship between Motivation Self- Concept and Academic Achievement of Students at a University of Limpopo Province, South Africa. International Journal of Educational Science 6(1) 19-25.

Tella A. (2007). The impact of motivation on student academic motivation and learning outcomes in mathematics among secondary school students in Nigeria. Eurasi Journal of Mathematics, Science and Technology Education 3(2), pp 149-55

How to cite this article: Kumavat S (2017), Academic Achievement Motivation among Junior College Science Faculty Students, International Journal of Indian Psychology, Volume 4, Issue 2, No. 96, ISSN:2348-5396 (e), ISSN:2349-3429 (p), DIP:18.01.189/20170402, ISBN:978-1365-84232-0 